\title{
Detection and Characterization of Extended-Spectrum $\beta$-lactamases in Salmonella Isolates of Meat, Milk and Human Clinical Samples from Different Districts of Chhattisgarh
}

\author{
Bhoomika $^{1 *}$, Sanjay Shakya ${ }^{1}$, Anil Patyal ${ }^{1}$ and Nitin Eknath Gade ${ }^{2}$
}

${ }^{1}$ Department of Veterinary Public Health and Epidemiology, ${ }^{2}$ Department of Veterinary Physiology and Biochemistry, College of Veterinary Science and Animal Husbandry, Chhattisgarh Kamdhenu Vishwa Vidyalaya, Anjora, Durg, Chhattisgarh, India

*Corresponding author

Keywords

ESBL,

S. enteritidis,

S. typhiurium,

Chicken, Chevon

Article Info

Accepted:

12 March 2019

Available Online:

10 April 2019
A B S T R A C T

Present study was undertaken to assess the hygiene quality of the meat, milk and also its prevalence on human population. A total of 330 samples including, chicken meat $(n=98)$, Chevon $(n=82)$, raw milk samples $(n=90)$ and human urine $(n=56)$ and stool samples $(n=4)$ Samples were aseptically collected from different districts of Chhattisgarh. Samples were processed for isolation of Salmonella further subjected for the different biochemical tests and confirmed by serotyping. Confirmed isolates were tested for its antibiogram pattern against 13 different antibiotic discs. Isolates were examined for phenotypic method for Extended Spectrum $\beta$-lactamases (ESBLs) by double disc synergy test and molecular characterization was done by multiplex PCR method. A total of $14.2 \%$ (47/330) samples were positive for Salmonella spp. highest prevalence rate of $27.55 \%$ (27/98) were observed in chicken meat, followed by $15 \%(9 / 60)$ and $13.41 \%(11 / 82)$ samples were found positive for Salmonella in contrary none of the milk samples found positive for Salmonella. Serotyping reveals the presence of S. typhiurium and S. enteritidis serotype among the isolates. Isolates showed highest sensitivity $(95.7 \%)$ against imipenem and however $89.2 \%$ isolates were found resistant to oxytetracylin. Out of 47 isolates $2.12 \%$ isolates were found as ESBL positive by phenotypic and genotypic method.

\section{Introduction}

Food-borne pathogens are major source of illness and death thus leading to a huge expenditure of money on healthcare (Nagrajan et al., 2018). The burden of food borne diseases is substantial: every year almost 1 in 10 people fall ill and 33 million of healthy life years are lost. Food borne diseases can be severe, especially for young children (WHO, 2018). Diarrheal diseases are the most common illnesses resulting from unsafe food, 550 million people falling ill each year, including 220 million children 
under the age of 5 years (WHO, 2018). Salmonellosis is one of the major food borne pathogens affects humans causing foodborne illnesses worldwide with serious implications in ill developed countries (Forshell and Wierup, 2006). Outbreaks due to Salmonella have been associated with a wide variety of foods especially those of animal origin (Hernandez et al., 2005) such as meat, chicken, egg, milk and sometimes vegetables in the food chain (Bouchrif et al., 2009; Naugle et al., 2006). Salmonella infections are largely classified into four clinical types (Bisi-Johnson and Obi, 2012); first, gastroenteritis caused by Salmonella enterica serovar Typhimurium; second, Bacteremia, osteomyelitis, reactive arthritis due to Salmonella typhimurium and Salmonella enteritidis infection; third, enteric fever caused by Salmonella Typhi and Salmonella Paratyphi and lastly, a carrier state in persons with previous infections (Owens and Warren, 2009; Klotchko and Wallace, 2009).

In developed countries antimicrobial drug resistance in non-typhoidal salmonella organisms is an almost inevitable consequence of the use of antimicrobial drugs in food producing animals. Such drugs may be used either therapeutically or prophylactically, or for growth promotion (feed additives). In developing countries contrast to the situation in developed countries such increases has been almost entirely associated with the use of antimicrobials in human medicine, both in hospitals and the community. Examples of increases in resistance in non-typhoidal salmonellas in developing countries, particularly in the Indian subcontinent, South East Asia, South and Central America and Africa, are exemplified by outbreaks caused by organisms such as Salmonella wien, Salmonella Typhimurium, Salmonella Johannesburg and Salmonella Oranienburg, all of which have caused numerous outbreaks of serious disease both in hospitals and the community over wide geographical areas (Rowe and Threlfall, 1984). Salmonella isolates harbouring Extended Spetrum $\beta$ Lactamases (ESBLs) have emerged worldwide during the last decade. This has caused concern since cephalosporins are drugs of choice for the treatment of salmonellosis in children. Different bla $a_{\mathrm{SHV}}$, $b l a_{\mathrm{TEM}}, b l a_{\mathrm{CTX}}$ and $b l a_{\mathrm{CMY}}$ genes have been found to encode ESBL resistance in Salmonella (Tzouvelekis et al., 2000; Mulvey et al., 2003).

\section{Materials and Methods}

\section{Study area and sampling}

The surveillance of non-typhoidal Salmonella serovars was done to evaluate the hygienic quality of meat (Chicken and Chevon) and milk, however human urine and stool samples were also collected to assess prevalence of organism in the community. A total of 330 samples including chicken meat $(n=98)$, Chevon $(\mathrm{n}=82)$, raw milk samples $(\mathrm{n}=90)$ and human urine $(n=56)$ and stool samples $(n=4)$ Samples were aseptically collected from Jagdalpur, Dantewada, Kanker and Kondagaon districts of Chhattisgarh (Table 1). Meat samples were collected from local meat shop and slaughter houses. Raw milk samples were collected from hotels and restaurants and Human stool and urine samples were collected from human hospital and from private clinics of above said districts. All the samples were collected aseptically and transported to the laboratory under refrigerated condition for analysis within 4-6 hrs.

\section{Isolation of Salmonella}

Isolation of Salmonella from milk and meat samples was performed as per the standard procedure described by ISO 6579: (2002) 
with slight modifications (ISO, 2002). Briefly $25 \mathrm{gm} / \mathrm{ml}$ of food sample were taken in $225 \mathrm{ml}$ of Buffered peptone water (BPW) (Himedia, India) and incubated overnight at $37^{\circ} \mathrm{C}$, after that $1 \mathrm{ml}$ of the culture from pre-enrichment was taken and incubated in tube containing 9ml of Tetra Thionate (TT) broth (Himedia, India) for selective enrichment and incubated at $37^{\circ} \mathrm{C}$ for $24 \mathrm{~h}$, further loop full culture from selective enrichment broth was streaked on to Brillient Green Agar (BGA) (Himedia, India) and Bismuth Sulfide Agar (BSA) (Himedia, India).

Isolation from human urine and stool samples were performed as per the method outlined by Nesa et al., (2011) and Singh et al., (2011), respectively. According to the protocols each samples were enriched in 1:10 ratio in freshly prepared Nutrient Broth (NB) and incubated at $37^{\circ} \mathrm{C}$ for $24 \mathrm{~h}$ and loopful culture from enrichment were streaked on BGA and BSA. Colonies appearing moderately large moist colorless surrounded by pink background on BGA and typical black colony surrounded by brownish-black zone with metallic sheen on BSA were considered as a presumptive Salmonella. The presumptive Salmonella Colonies (3-4 colonies/plates) were further subjected to biochemical characterization.

\section{Identification of Salmonella}

\section{Biochemical characterization}

The presumptive colonies of Salmonella were further subjected to biochemical tests viz., triple sugar iron (TSI), Urease broth, indole, methyl red, Voges-Proskauer and Citrate test (IMViC) as per the procedure described by Agarwal et al., (2003). The colonies showing negative urease test with (-+-+) IMViC pattern were further inoculated on TSI slants and colonies producing alkaline slant (pink) and acidic butt (yellow) with or without $\mathrm{H} 2 \mathrm{~S}$ production (blackening) were considered as a biochemically confirmed Salmonella isolates.

\section{Serotyping of Salmonella isolates}

All Salmonella isolates were further submitted to the National Salmonella and Escherichia Centre, Central Research Institute, Kasauli (Himachal Pradesh) for serotyping.

\section{Antimicrobial susceptibility pattern}

All Salmonella isolates were tested for their antimicrobial susceptibility pattern by disc diffusion method as described earlier by Bauer and Kirby (1966). Isolates were tested against 11 commercial antibiotic disc (Himedia, India) on Mueller Hinton Agar plates (MHA) (Himedia, India). Antibiotic discs including Oxytetracycline (30 mcg), Cephalexin (30mcg), Ciprofloxacin (5mcg), Gentamicin (30mcg), Cefotaxime (10 mcg), Ampicillin (10mcg), Ceftazidime (30 mcg), aztreonam (30mcg), Imipenem (10mcg), Cefixime (5mcg), and Meropenem (10mcg) were used in the study. The diameter of the zones of complete inhibition was measured and compared with the zone size interpretation chart provided by the supplier and were graded as sensitive, intermediate and resistant. The multiple antibiotic resistance (MAR) index was also calculated for all Salmonella isolates following the protocol described by (Krumperman, 1983) by applying formula $a / b$ where " $a$ " is the number of antibiotics to which an isolate was resistant and " $b$ " is the number of antibiotics to which the isolates were exposed.

\section{Detection of ESBL producing isolates}

The isolate with a zone of inhibition diameter of $\leq 17 \mathrm{~mm}$ for aztreonam, $\leq 17 \mathrm{~mm}$ for Ceftazidime, and $\leq 22 \mathrm{~mm}$ for cefotaxime in disc diffusion susceptibility testing were considered further for screening for ESBL phenotypes. 


\section{Double disc synergy test}

The phenotypic confirmatory test for ESBL producers was performed as per Clinical Laboratory Standard Institute (CLSI, 2012) guidelines. For this purpose, 5 antibiotics cefotaxime $(10 \mu \mathrm{g})$, ceftazidime $(30 \mu \mathrm{g})$, aztreonam $(30 \mu \mathrm{g})$, cefotaxime- clavulanic acid $(30 / 10 \mu \mathrm{g})$, amoxicillin-clavulanic acid $(30 \mu \mathrm{g})$ were used. Discs were placed $25 \mathrm{~mm}$ apart on a MHA plate inoculated with 0.5 McFarland suspension of the test isolate. Plates were incubated at $35^{\circ} \mathrm{C}$ for $18 \mathrm{hrs}$. After incubation the zone diameter around each of disc was measured.

A difference of $\geq 5 \mathrm{~mm}$ between the zone diameters of either of the cephalosporin discs and their respective cephalosporin/ clavulanic acid discs were considered as positive phenotypic confirmatory test for ESBL producers.

\section{Molecular characterization of ESBL producing isolates}

Isolates which showing positive ESBL production in double disc synergy test were further subjected to test the presence of bla genes. Extraction of bacterial genomic DNA was performed by snap chill method, briefly, a single colony was inoculated into NB medium and was incubated at $37^{\circ} \mathrm{C}$ overnight. Then, $1.5 \mathrm{ml}$ of the bacterial culture was centrifuged at $8000 \mathrm{rpm}$ and the pellet was washed three times in PBS and eluted in 100 $\mu 1$ of Nuclease Free Water (NFW), kept in to boiling water bath for 10 minutes, after that pellet is immediately chilled in ice.

Detection of the gene sequence coding for the TEM, SHV, CTX-M enzymes were performed by the multiplex PCR as previously described with slight modifications (Apaka et al., 2010) (Table 2).

\section{Results and Discussion}

A total of the 330 samples including 180 meat samples (98 chicken meats and 82 chevon), 90 milk sample and 60 human urine and stool samples were screened for isolation of Salmonella spp. Forty seven (14.2\%) samples were found positive by culture and biochemical tests. Out of 47 isolates, 27 (57.4 $\%)$ were from chicken, $11(23.4 \%)$ from chevon meat and $9(19.1 \%)$ from human urine and stool samples. District wise highest prevalence was observed in Dantewada district $(17.7 \%)$ followed by Kondagaon (16.5\%), Jagdalpur (12.6\%) and Kanker (9.2\%) (Table 1). The prevalence of Salmonella in chicken meat was observed $27.6 \%$ which is in agreement with the report of Moon (2011) and Bharathy et al., (2015) However lower prevalence rate were also reported by several workers (Kumar and Lakhera, 2013 and Saad et al., 2011). The significantly higher prevalence of $56 \%$ was reported in chicken meat by Ramya et al., (2012).

In chevon, $13.4 \%$ prevalence of Salmonella was observed which is closely related with the findings of Panda et al., (2012) and Ahmad et al., (2013) who reported 10-13.9 \% prevalence (Table 1). However lower prevalence rates varied between 2\% (Zubir et al., 2012) to 9\% (Naik et al., 2015) were reported by others. On contrary, Moon (2011) reported higher prevalence rate of $38.3 \%$.

In human urine and stool samples, 15\% prevalence of Salmonella was observed (Table 1). Nesa et al., (2011) and Warjri et al., (2015) reported $16.1 \%$ prevalence rate in stool samples which corroborate with the present findings. However, Babu et al., (2010) and Singh et al., (2011) reported lower prevalence rate. On the contrary, higher prevalence rate were reported by $\mathrm{Chiu}$ and $\mathrm{Ou}$ (1996) and Murugkar et al., (2005). 
Table.1 Prevalence of Salmonella spp. in chicken meat, chevon and human urine and stool samples in different districts of Chhattisgarh

\begin{tabular}{|c|c|c|c|c|c|c|c|c|c|c|}
\hline \multirow[t]{2}{*}{$\begin{array}{l}\mathbf{S} . \\
\mathbf{N}\end{array}$} & \multirow[t]{2}{*}{ Districts } & \multicolumn{2}{|c|}{ Chicken meat } & \multicolumn{2}{|c|}{ Chevon } & \multicolumn{2}{|c|}{ Milk } & \multicolumn{2}{|c|}{$\begin{array}{l}\text { Human urine and stool } \\
\text { samples }\end{array}$} & \multirow[t]{2}{*}{ Total } \\
\hline & & $\begin{array}{l}\text { No. of } \\
\text { samples } \\
\text { analysed }\end{array}$ & $\begin{array}{l}\text { No. of } \\
\text { samples } \\
\text { positive } \\
(\%)\end{array}$ & $\begin{array}{l}\text { No. of } \\
\text { samples } \\
\text { analysed }\end{array}$ & $\begin{array}{l}\text { No. of } \\
\text { samples } \\
\text { positive } \\
(\%)\end{array}$ & $\begin{array}{l}\text { No. of } \\
\text { samples } \\
\text { analysed }\end{array}$ & $\begin{array}{l}\text { No. of } \\
\text { samples } \\
\text { positive } \\
(\%)\end{array}$ & $\begin{array}{l}\text { No. of } \\
\text { samples } \\
\text { analysed }\end{array}$ & $\begin{array}{l}\text { No. of } \\
\text { samples } \\
\text { positive } \\
(\%)\end{array}$ & \\
\hline 01. & Jagdalpur & 25 & $\begin{array}{l}8 \\
(32 \%)\end{array}$ & 25 & $\begin{array}{l}0 \\
(0.00 \%)\end{array}$ & 30 & $\begin{array}{l}0 \\
(0.00 \%)\end{array}$ & 15 & $4(26.66 \%)$ & $\begin{array}{l}12 \\
(12.63 \%)\end{array}$ \\
\hline 02. & Dantewada & 25 & $\begin{array}{l}11 \\
(44 \%)\end{array}$ & 25 & $\begin{array}{l}3 \\
(12 \%)\end{array}$ & 20 & $\begin{array}{l}0 \\
(0.00 \%)\end{array}$ & 15 & $\begin{array}{l}1 \\
(6.66 \%)\end{array}$ & $\begin{array}{l}15 \\
(17.64 \%)\end{array}$ \\
\hline 03. & Kondagaon & 25 & $\begin{array}{l}6 \\
(24 \%)\end{array}$ & 25 & $\begin{array}{l}7 \\
(28 \%)\end{array}$ & 20 & $\begin{array}{l}0 \\
(0.00 \%)\end{array}$ & 15 & 1 & $\begin{array}{l}14 \\
(16.47 \%)\end{array}$ \\
\hline \multirow[t]{2}{*}{04.} & Kanker & 23 & $\begin{array}{l}2 \\
(8.69 \%)\end{array}$ & 7 & $\begin{array}{l}1 \\
(4 \%)\end{array}$ & 20 & $\begin{array}{l}0 \\
(0.00 \%)\end{array}$ & 15 & $\begin{array}{l}3 \\
(20 \%)\end{array}$ & $\begin{array}{l}6 \\
(9.23 \%)\end{array}$ \\
\hline & Total & 98 & $\begin{array}{l}27 \\
(27.55 \%)\end{array}$ & 82 & $\begin{array}{l}11 \\
(13.41 \%)\end{array}$ & 90 & $\begin{array}{l}0 \\
(0.00 \%)\end{array}$ & 60 & $\begin{array}{l}9 \\
(15 \%)\end{array}$ & $\begin{array}{l}47 \\
(14.24 \%)\end{array}$ \\
\hline
\end{tabular}

Table.2 Detail of the primers used in multiplex PCR

\begin{tabular}{|c|c|c|c|}
\hline Gene & Primer sequence & Length & References \\
\hline$b l a_{\mathrm{SHV}}$ & $\begin{array}{l}\text { 5'- ATG CGT TAT ATT CGC CTG TG - 3' } \\
\text { 5'- TGC TTT GTT ATT CGG GCC AA - 3' }\end{array}$ & 747-bp & $\begin{array}{l}\text { (Paterson et al., } \\
\text { 2003) }\end{array}$ \\
\hline bla $a_{\text {TEM }}$ & $\begin{array}{l}5^{\prime},- \text { TCG CCG CAT ACA CTA TTC TCA GAA TGA - 3' } \\
5^{\prime}-\text { ACG CTC ACC GGC TCC AGA TTT AT - 3' }\end{array}$ & 445-bp & $\begin{array}{l}\text { (Apaka et al., } \\
\text { 2010) }\end{array}$ \\
\hline$b^{\prime} a_{\text {СтХ-м }}$ & $\begin{array}{l}5^{\prime},- \text { ATG TGC AGY ACC AGT AAR GTK ATG GC - 3' } \\
5^{\prime}-\text { TGG GTR AAR TAR GTS ACC AGA AYC AGC GG-3', }\end{array}$ & 593-bp & (Boyd et al., 2004) \\
\hline
\end{tabular}

Table.3 Prevalence of resistant isolates of Salmonella spp. and E. coli in chicken meat, chevon and human urine and stool sample

\begin{tabular}{|c|c|c|c|c|}
\hline \multirow[t]{2}{*}{ S.N. } & \multirow[t]{2}{*}{ Antibiotic disc } & \multicolumn{3}{|c|}{ No. of resistant isolates (\%) } \\
\hline & & Chicken $(n=27)$ & Chevon $(n=11)$ & $\begin{array}{l}\text { Human urine } \\
\text { and stool }(n=9)\end{array}$ \\
\hline 1. & Ampicillin (AMP) & $4(14.81 \%)$ & $1(9.09 \%)$ & $3(33.33 \%)$ \\
\hline 2. & Oxytetracycline (O) & $24(88.88 \%)$ & $11(100 \%)$ & $4(44.44 \%)$ \\
\hline 3. & Gentamicin (GEN) & $1(3.70 \%)$ & $1(9.09 \%)$ & $0(0.00 \%)$ \\
\hline 4. & Ciprofloxacin (CIP) & $0(0.00 \%)$ & $0(0.00 \%)$ & $3(33.33 \%)$ \\
\hline 5. & Cephalexin(CN) & $3(11.11 \%)$ & $1(9.0 \%)$ & $3(33.33 \%)$ \\
\hline 6. & Ceftazidime (CAZ) & $0(0.00 \%)$ & $0(0.00 \%)$ & $1(11.11 \%)$ \\
\hline 7. & Cefixime (CFM) & $2(7.40 \%)$ & $0(0.00 \%)$ & $3(33.33 \%)$ \\
\hline 8. & Cefotaxime (CTX) & $2(7.40 \%)$ & $0(0.00 \%)$ & $1(11.11 \%)$ \\
\hline 9. & Aztreonam (AT) & $0(0.00 \%)$ & $0(0.00 \%)$ & $1(11.11 \%)$ \\
\hline 10. & Meropenem (MRP) & $1(3.70 \%)$ & $0(0.00 \%)$ & $1(11.11 \%)$ \\
\hline 11. & Imipenem (IPM) & $1(3.70 \%)$ & $0(0.00 \%)$ & $0(0.00 \%)$ \\
\hline
\end{tabular}


Table.4 MAR index for Salmonella isolate from various district of Chhattisgarh

\begin{tabular}{|c|c|c|c|c|c|c|c|c|c|c|c|c|c|}
\hline \multirow[t]{2}{*}{ S.N } & \multirow[t]{2}{*}{ District } & \multicolumn{11}{|c|}{ MAR index for Salmonella isolates } & \multirow{2}{*}{$\begin{array}{c}\text { Total } \\
\text { isolates }\end{array}$} \\
\hline & & 0.00 & 0.09 & 0.18 & 0.27 & 0.36 & 0.45 & 0.54 & 0.63 & 0.72 & 0.81 & 0.90 & \\
\hline 1. & Jagdalpur & 1 & 4 & 6 & - & - & 1 & - & - & - & - & - & 12 \\
\hline 2. & Dantewada & - & 13 & - & 1 & - & - & - & - & 1 & - & - & 15 \\
\hline 3. & Kanker & 2 & 2 & - & 2 & - & - & - & - & - & - & - & 6 \\
\hline 4. & Kondagaon & - & 11 & 1 & 1 & 1 & - & - & - & - & - & - & 14 \\
\hline & Total & 3 & 30 & 7 & 4 & 1 & 1 & - & - & 1 & - & - & 47 \\
\hline
\end{tabular}

In the present study no Salmonella spp. was isolated from raw milk. Differences in the prevalence rate of Salmonella isolates with the previous study may be attributed by the multiple factors, such as geographic and seasonal variation, variations in sampling procedure and sample size, animal management practices, hygienic conditions during production and processing of meat and meat products or due to differences in the sensitivity and specificity of different isolation methods used.

Isolates were confirmed by serotyping and found they belongs to $S$. enteritidis and $S$. typhimurium serotypes which both are the most common serotype isolated from food borne outbreak. Our findings show resemblance with the reports of Vose et al., 2010.

All the 47 Salmonella isolates were tested for their antibiotic sensitivity against 11 antibiotics by disc diffusion method and it was found that $95.7 \%$ isolates were found sensitive to imipenem. Whereas $91.5 \%$ isolates were sensitive for aztreonam and ceftazidime. However, $89.4 \%$ isolates were sensitive to gentamicin and ciprofloxacin. Variable sensitivity of $85.1 \%, 82.9 \%, 80.9 \%$, $78.7 \%, 74.5 \%$ were detected for meropenem, cefixime, ampicillin and cephalexin, cefotaxime respectively. On contrary $82.9 \%$ isolates were highly resistant against oxytetracycline (Table 3). Similar type of pattern was reported by Naik et al., (2015) who reported that Salmonella isolates were $100 \%$ sensitive to ciprofloxacin while $96.87 \%, 96.87 \%$ and $93.75 \%$ were sensitive to gentamicin, imipenem, and ceftazidime, respectively. Varying degree of sensitivity was found against cefixime (81.25\%), cephalexin (78.12\%), ampicillin (75\%) and cefotaxime $(59.37 \%)$.

Highest MAR index for Salmonella isolates were 0.72 ( 1 isolate) followed by 0.45 (1 isolate), 0.36 (1 isolate), 0.27 (4 isolates), 0.18 (7 isolates) and 0.09 (30 isolates). However 0.00 MAR index were recorded in 3 isolates (Table 4). The prevalence of MAR Salmonella spp. was also reported by others (Krumperman, 1983, Jaulkar et al., 2011 and Naik et al., 2015). The pathogens with higher indices of MAR in foods of animal origin may possibly be introduced from the environment. The wide use and abuse of antibiotic in mass production of live stock has promoted the emergence of and maintains the prevalence of MAR E.coli and Salmonella spp. in the faecal environment of these animals.

The isolates showed resistance against cefotaxime, Ceftazidime and Aztreonam were further tested for ESBL production. Among 47 isolates of Salmonella spp. only $1(2.12 \%)$ isolate was found ESBL producer which was recovered from urine sample. Similar findings were also reported by Irajian et al., 2009 and Parvin et al., 2015. 
Molecular characterisation of the isolates for the detection of ESBL genes $\left(b l_{\mathrm{SHV}}, b l a_{\mathrm{TEM}}\right.$ and $b l a_{\text {(TX-M) }}$ were performed by using multiplex PCR. Out of 47 Salmonella isolates One Salmonella isolate $2.12 \%$ expressed the presence of bla $a_{\mathrm{TEM}}$ gene. Similar type of result was also reported by Apaka et al., (2010) highest prevalence of bla $a_{\text {TEM }}$ gene than $b l a_{\mathrm{CTX}-\mathrm{M}}$ and lowest prevalence of $b l a_{\mathrm{SHV}}$ gene. The genus Salmonella is not common hospital flora, and ESBL production with multiple antibiotic resistances is rarely associated with this organism. Constant antibiotic pressure can select multidrugresistance and ESBL-producing bacteria, enabling their transmission among hospitalized patients. We cannot exclude the possibility that this mechanism of resistance was due to selective pressure, despite the evidence that very few patients had been exposed to the third-generation cephalosporins before isolation of the SIESBL

\section{Acknowledgments}

The authors are highly thankful to the Dean, College of Veterinary Science and Animal Husbandry, Chhattisgarh Kamdhenu Vishwa Vidyalaya, Anjora,Durg, Chhattisgarh, India for providing necessary financial assistance and instrumentation facilities to carry out this research work.

\section{References}

Agarwal, R. K., Bhilegaonkar, K. N., Singh D. K., Kumar, A. and Rathore, R. S. 2003. Laboratory manual for the isolation and identification of foodborne pathogens. ICAR publication, $1^{\text {st }}$ edition.

Ahmad, M.U.D., Sarwar, A., Najeeb, M.I., Nawaz, M., Anjum, A.A., Ali, M.A. and Mansur, N. 2013. Assessment of microbial load of raw meat at abattoirs and retail outlets. Journal of Animal Plant Science. 23(3): 745-748.
Akpaka, P.E., Legall, B. and Padman, J. 2010. Molecular detection and epidemiology of extended-spectrum beta-lactamase genes prevalent in clinical isolates of Klebsiella pneumoniae and $E$ coli from Trinidad and Tobago. West Indian Medical Journal. 59(6): 591-596.

Babu, U., Prabhakar, K., Sadaiyappan, R., and Yelavarthi, L. S. 2010. Prevalence of extended spectrum beta lactamases in Salmonella species isolated from patients with acute gastroenteritis. Indian Journal of Gastroenterology. 29: 201-204.

Bauer, A. W., Kirby, W. M. M., Shernis, J. C. and Truck, M. 1966. Antibiotic susceptibility testing by a standardized single disc method. American Journal of Clinical Pathology. 45: 493-496.

Bharathy, S., Swetha, C.S. and Sudhanthirakodi, S. 2015. A prospective study on antibiogram pattern for salmonella isolated from poultry origin and milk samples of local chicken retailers and local vendors in Tirupathi, India. International Journal of Agriculture and Science \& Veterinary Medicine. 3: 11-16.

Bisi-Johnson, M.A. and Obi, C.L. 2012. Escherichia coli and Salmonella species: molecular landscape and therapeutic considerations: a review. Advances in Medical Sciences, 1(1): 1-16.

Bouchrif, B., Paglietti, B., Murgia, M., Piana, A., Cohen, N., Ennaji, M.M., Rubino, S. and Timinouni, M. 2009. Prevalence and antibiotic-resistance of Salmonella isolated from food in Morocco. The Journal of Infection in Developing Countries. 3(01): 035-040.

Chiu, C. and Ou, J. T. 1996. Rapid identification of Salmonella serovars in feces by specific detection of virulence genes, inv A and $s p v \mathrm{C}$, by an enrichment broth culture-multiplex PCR combination assay. Journal of Clinical Microbiology. 34: 2619-2622.

CLSI (2012). Performance Standards for Antimicrobial Susceptibility testing: Twenty Second Informational 
Supplement M100-S22. Wayne, PA, USA.

Forshell, L.P. and Wierup, M. 2006. Salmonella contamination: a significant challenge to the global marketing of animal food products. Rev. sci. tech. Off. int. Epiz. 25(2): 541-554.

Hernandez, T., Sierra, A., Rodriguez-Alvarez, C., Torres, A., Arevalo, M.P., Calvo, M. and Arias, A. 2005. Salmonella enterica serotypes isolated from imported frozen chicken meat in the Canary Islands. Journal of food protection. 68(12): 27022706.

Irajian, G., Ranjbar, R. and Moghadas, A. J. 2009. Detection of extended spectrum beta lactamase producing Salmonella spp. and multidrug resistance pattern. Iranian Journal of Pathology. 4: 128-132.

ISO 6579:2002 standard: Microbiology of food and animal feeding stuffs - Horizontal method for the detection of Salmonella spp. ISO Central Secretariat; 1, rue de Varembé, CH. 1211,Genève 20, Schweitzerland. $4^{\text {th }}$ edition.

Jaulkar, A. D., Zade, N. N., Katre, D. D., Khan, D. D., Chaudhary, S. P. and Shinde, S. V. 2011. Plasmid characterization of Salmonella isolated from foods of animal origin. Journal of Veterinary Public Health. 9: 25-28.

Jazayeri Moghadas, A., Irajian, G. and Ranjbar, R. 2009. Detection of extended spectrum beta lactamase producing Salmonella spp. and multidrug resistance pattern. Iranian Journal of Pathology. 4(3): 128132.

Jones, T.F., Ingram, L.A., Cieslak, P.R., Vugia, D.J., Tobin-D'Angelo, M., Hurd, S., Medus, C., Cronquist, A. and Angulo, F.J., 2008. Salmonellosis outcomes differ substantially by serotype. The Journal of infectious diseases, 198(1), pp.109-114.

Klotchko, A. and Wallace, M.R. 2009. Salmonellosis: Treatment and Medication. Available from: http://www. emedicine.medscape.com/article/228174 -overview. Accessed on 15-04-2015.
Krumperman, P. H. 1985. Multiple antibiotics indexing of $E$. coli to identify high risk sources faecal contamination of foods. Applied and Environmental Microbiology. 46: 165-170.

Kumar, K. and Lakhera, P.C. 2013. Isolation, plasmid profiling and antibiogram of Salmonella from poultry meat and environmental sources. Journal of Animal Research. 3(1): 53.

Moon, A.H. 2011. Studies on: Prevalence and antibiogram of Salmonella species of polluted meat origin. Asiatic J. Biotechnol. Resou. 2(04): 447-453.

Mulvey, M.R., Soule, G., Boyd, D., Demczuk, W. and Ahmed, R. 2003. Characterization of the first extendedspectrum beta-lactamase-producing Salmonella isolate identified in Canada. Journal of clinical microbiology. 41(1): 460-462.

Murugkar, H. V., Rahman, H., Kumar, A. and Bhattacharya, D. 2005. Isolation, phage typing \& antibiogram of Salmonella from man \& animals in northeastern India. Indian Journal of Medical Research. 122: 237-242.

Nagarajan, V., Wahab, A., Shiraj, S. and Alex, L. 2018. Study of Bacterial Contamination of Raw Meat in Hyderabad. MOJ prteomics and bioinformatics. 7 (1).

Naik, V.K., Shakya, S., Patyal, A., Gade, N.E., Bhoomika. (2015). Isolation and molecular characterization of Salmonella spp. from chevon and chicken meat collected from different districts of Chhattisgarh, India. Veterinary World. 8: 702-706.

Naugle, A.L., Barlow, K.E., Eblen, D.R., Teter, V. and Umholtz, R. 2006. US Food Safety and Inspection Service testing for Salmonella in selected raw meat and poultry products in the United States, 1998 through 2003: analysis of set results. Journal of food protection. 69(11): 2607-2614.

Nesa, M.K., Khan, M.S.R. and Alam, M. 2011. Isolation, identification and 
characterization of salmonella serovars from diarrhoeic stool samples of human. Bangladesh Journal of Veterinary Medicine. 9(1): 85-93.

Owens, M.D. and Warren, D.A. (2009) Salmonella Infection. Emedicine: Emergency Medicine Available fromhttp://www.emedicine.medscapeco $\mathrm{m} /$ article/785774-overview. html. Accessed on 15-04-2015.

Panda, A.K., Kumar, A. and Thakur, S.D. 2012. Evaluation of bacteriological quality of meat and meat products in Palam Valley of North Western Himalayas. Journal of Veterinary Public Health. 10(1): 21-25.

Parvin, A., Hasan, M. M., Talukder, K. A., Azmi, I. J. and Hasan, M. R. 2015. Extended-spectrum beta-lactamaseproducing Salmonella species isolated from diarrhoeal patients in Bangladesh: characterization and their dissemination through conjugation. British Microbiology Research Journal. 6: 4153.

Ramya, P., Madhavarao, T. and Rao, L.V. 2012. Study on the incidence of Salmonella enteritidis in poultry and meat samples by cultural and PCR methods. Veterinary World. 5(9): 541-545.

Saad, M.S., Edris, A.M., Shaltout, F.A. and Edris-Shimaa, N. 2011. Isolation and identification of Salmonellae and E.coli from meat and poultry cuts by using multiplex PCR. Benha Veterinary Medical Journal. 22: 152-160.
Singh, V., Sharma, P., Kaushal, S., Sharma, R., Tyagi, A. and Chauhan, P.K. 2011. Prevalence and Antibiogram Pattern of Salmonella Causing UTI Infection. Asian Journal of Pharmacy \& Life Science. 1(2): 179-182.

Tzouvelekis, L.S., Tzelepi, E., Tassios, P.T. and Legakis, N.J. 2000. CTX-M-type $\beta$ lactamases: an emerging group of extended-spectrum enzymes. International Journal of Antimicrobial Agents. 14(2): 137-142.

Vose, D., Koupeev, T. and Mintiens, K. 2011. A Quantitative Microbiological Risk Assessment of Salmonella spp. in broiler (Gallus gallus) meat production. EFSA Supporting Publications. 8(7):183

Warjri, I., Dutta, T.K., Lalzampuia, H. and Chandra, R. 2015. Detection and characterization of extended-spectrum $\beta$ lactamases (blaCTX-M-1 and blaSHV) producing Escherichia coli, Salmonella spp. and Klebsiella pneumoniae isolated from humans in Mizoram. Veterinary World. 8(5): 599.

World health organization. 2018. Non Typhoidal Salmonella factsheet.

Zubair, A.I. and Ibrahim, K.S. 2013. Isolation of Salmonella from slaughtered animals and sewage at Zakho abattoir, Kurdistan Region, Iraq. Research Opinions in Animal and Veterinary Sciences. 3(1): 20-24.

\section{How to cite this article:}

Bhoomika, Sanjay Shakya, Anil Patyal and Nitin Eknath Gade. 2019. Detection and Characterization of Extended-spectrum $\beta$-lactamases in Salmonella Isolates of Meat, Milk and Human Clinical Samples from Different Districts of Chhattisgarh. Int.J.Curr.Microbiol.App.Sci. 8(04): 1639-1647. doi: https://doi.org/10.20546/ijcmas.2019.804.191 